\title{
WHICH FACTORS DRIVE SUSTAINABILITY INITIATIVES IN SMALL AND MEDIUM-SIZED ENTERPRISES? A MULTIPLE-CASE STUDY IN THE LEATHER-FOOTWEAR INDUSTRY IN BRAZIL
}

\author{
Maira Petrini \\ Doutora em Administração de Empresas \\ Pontifícia Universidade Católica do Rio Grande do Sul - PUCRS \\ Porto Alegre - Rio Grande do Sul - Brasil \\ Léa Schmatz Back \\ Mestre em Administração e Negócios \\ Pontifícia Universidade Católica do Rio Grande do Sul - PUCRS \\ Porto Alegre - Rio Grande do Sul - Brasil \\ Ana Clarissa Matte Zanardo dos Santos \\ Doutora em Administração de Empresas \\ Pontifícia Universidade Católica do Rio Grande do Sul - PUCRS \\ Porto Alegre - Rio Grande do Sul - Brasil
}

\section{ABSTRACT}

This study analysed which factors drive (or not) the adoption of sustainability initiatives in small and medium-sized enterprises. Through qualitative approach, we collected data (semi-structured interviews, observations and documents) from eleven organizations from the leather-footwear industry in southern Brazil. This study contributes to the existing literature in two ways. First, the factors are structured into a framework according to two perspectives: (1) internal or external and (2) facilitators or inhibitors. Regarding external factors, the findings show legislation is the only factor that influences all the organizations. However, when legislation was the only factor, it is related to organisations with low levels of presence of sustainability initiatives. The lack of government incentives was found to be an important inhibitor to the adoption of sustainability initiatives. The second factor, according to our findings indicates that there are two possible paths lead to the adoption of sustainability initiatives by SMEs: one based on the values held by the leaders and members of the organisation and the other guided by concern for the organisation's reputation. We identified a possible link between the presence of women in management and the entrepreneur's vision regarding the adoption of sustainability initiatives. Our framework can be used in quantitative studies to establish which factors are dependent and/or independent variables in order to identify the degree of correlation between them.

Keywords: Corporation social responsibility; Small and medium-sized enterprises; Sustainability initiatives; Drivers for sustainability.

\section{QUAIS FATORES CONDUZEM AS INICIATIVAS DE SUSTENTABILIDADE EM EMPRESAS DE PEQUENAS E MÉDIAS? UM ESTUDO DE CASO MÚLTIPLE NA INDÚSTRIA DE CALÇADOS DE COURO NO BRASIL}

\section{RESUMO}

Este estudo analisou quais fatores impulsionam (ou não) a adoção de iniciativas de sustentabilidade em pequenas e médias empresas. Adotando uma abordagem qualitativa, coletamos dados (entrevistas semiestruturadas, observações e documentos) em onze organizações da indústria do couro e calçados no sul do Brasil. Este estudo contribui para a pesquisa existente de duas maneiras. Primeiro, os fatores são estruturados em uma estrutura de acordo com duas perspectivas: (1) internos ou externos e (2) facilitadores ou inibidores. Quanto aos fatores externos, os resultados mostram que a legislação é o único fator que influencia todas as organizações. No entanto, quando a legislação foi o único fator, está relacionada a organizações com baixos níveis de presença de iniciativas de sustentabilidade. A falta de incentivos governamentais foi considerada um inibidor importante para a adoção de iniciativas de sustentabilidade. Em segundo lugar, nossas descobertas indicam que existem dois caminhos possíveis que levam à adoção de iniciativas de sustentabilidade pelas PME: uma baseada nos valores detidos pelos líderes e membros da organização e outra orientada pela preocupação com a reputação da organização. Identificamos um possível vínculo entre a presença de mulheres na gestão e a visão do empreendedor sobre a adoção de iniciativas de sustentabilidade. Nossa estrutura pode ser usada em estudos quantitativos para estabelecer quais fatores são dependentes e / ou variáveis independentes para identificar o grau de correlação entre eles.

Palavras-chave: Responsabilidade social das empresas; Pequenas e médias empresas; Iniciativas de sustentabilidade; Drivers para sustentabilidade. 


\section{INTRODUCTION}

Sustainable Development (SD) is on the agenda for organisations, as indicated by the concept of Corporate Social Responsibility (CSR), which encompasses the economic, legal and ethical dimensions of an organisation's activities, with special emphasis on their social and environmental aspects (Carroll, 1999; Elkington, 1998). The ongoing debate on sustainability involves setting goals related to achieving a healthy and balanced environment (environmental), harmonious development (economic) and the reduction of inequality (social) (Gallardo-Vásquez \& Sanches-Hernandez, 2014).

On the one hand, large organisations have become a key focus of attention in the sustainability debate (Johannsdottir, 2015; Lozano, 2013; Moyeen \& Courvisanos, 2012). On the other hand, the context of small and medium-sized enterprises (SMEs) is seen to be favourable to the adoption of such initiatives (Halme \& Korpela, 2014; Stewart \& Gapp, 2014). We therefore address the following research question: What have been the factors that drive sustainability initiatives within the context of small and medium-sized enterprises?

A review of the literature have already identified several factors that drive SMEs to adopt sustainability initiatives (Nikolaou, Nikolaidou \& Tsagarakis, 2015; Reverte, 2015; Singh, Olugu \& Fallahpour, 2014; Raufflet, Cruz \& Bres, 2014; Williams \& Schaefer, 2013; Schaltegger, 2011). Therefore, if our objective is to analyse factors that drive SMEs to become more socially and environmentally sustainable, in what ways is our proposal different? First, our research investigates not only environmental issues but also the social dimension, since most studies were found to focus exclusively on factors related to environmental issues. Second, we look at the relationships existing between the characteristics of the SMEs, the level of presence of sustainability initiatives and the factors identified in the literature. Furthermore, we seek to organize a single view of all the factors by proposing a framework based not only on the literature, but also on data collected in the field. To achieve that, we starting from factors to sustainability in SMEs identified in the 30 articles reviewed in the literature.

To explore our research question, the method adopted was a multiple case study including 11 organisations in the leather-footwear industry, which is the largest generator of hazardous industrial solid waste in the state of Rio Grande do Sul (RS). In RS, the leather-footwear industry is responsible for $62 \%$ of the total industrial waste, followed by the mechanical $(11 \%)$ and metallurgical (11\%) sectors (FEPAM, 2013). Data collection was conducted through semistructured interviews, observation and document research, using content analysis in the data analysis.

Our results propose a framework where the factors are structured according to two perspectives: (1) internal or external and (2) facilitators or inhibitors. Therefore, our study makes two main contributions. First, from a theoretical viewpoint, our results shed light on which factors drive (or not) sustainability initiatives. We identified propositions to be tested and the proposed framework can be used in quantitative studies to establish which factors are dependent and/or independent variables in order to identify the degree of correlation between them. From a practice viewpoint, the framework can be of use to SMEs that are interested in conducting an organisational diagnosis and planning sustainability initiatives, offering a tool on how companies can be more effective to becoming more sustainable.

\section{SUSTAINABILITY AND CORPORATE SOCIAL RESPONSIBILITY}

The concept of SD involves environmental, social and economic aspects and was raised in the Brundtland Report in 1987. The central idea is to meet the needs of present generations without compromising the ability of future generations to meet their own needs. In seeking to reconcile economic growth with environmental preservation as well as ending poverty in the world, this report argues there is no development, if economic growth does not consider the quality of life of 
the people and society. Within the debate on SD, the concept of CSR has emerged. Adopting CSR can be understood as one way in which organisations can engage in SD. In an interconnected world, sustainable organisations and societies must find ways to survive without consuming their own capital, which in this context includes natural resources such as water, air, energy and food. According to Carroll (1999), the organisation that applies the concept of CSR takes action to meet the expectations of society in the economic, legal and ethical dimensions. Elkington (1998) proposed the concept of the 'Triple Bottom-Line' (TBL) as a model for organisations to interpret sustainability through the integration of the economic, environmental and social dimensions. In this model, the economic dimension is concerned with the efficiency of the production processes and changes in consumption patterns geared to long-term sustainable economic reproduction. The social dimension involves respect for human rights, not merely legal compliance, but instead fostering them and preventing their violation. The environmental dimension concerns the conservation of natural resources and the production of renewable resources. Garriga and Melé (2013) classify the main theories regarding CSR into four groups: (1) instrumental theories, where the organisation is seen only as a tool to generate wealth and its social activities are just a means to achieve economic results; (2) political theories, which are concerned with the power of organisations in society and the responsible use of that power in the political arena; (3) integrative theories, in which the organisation is seen to focus on meeting social demands; and (4) ethical theories, based on the ethical responsibilities of organisations towards society. In short, CSR constitutes organisational and political actions that take into account the expectations of stakeholders and the triple bottom line of economic, social and environmental performance, influenced and implemented at all levels: institutional, organisational and individual (Aguinis \& Glavas, 2012). In the next section we seek to identify which factors influence the adoption of such initiatives.

\subsection{Drivers for Sustainability}

Laurinkevičiūtè and Stasiškienè (2011) state that, in the face of competition and in order to improve their performance and grow in the market, SMEs should follow the principles of SD by integrating the business strategy and the economic, environmental sustainability and social performance. To achieve that, Murillo and Lozano (2006) suggest SMEs incorporate CSR policies, while noting the drivers on which they depend, such as: a) characteristics and values of the founder; b) competitive impact; c) innovation opportunities; d) desire to differentiate; e) legal regulations; f) organisational mission.

Santos and Silva (2010) see the engagement of SMEs with sustainability as being based on interests and/or beliefs, in which many entrepreneurs are influenced by external pressures, while, on the other hand, some adopt 'a spirit of responsible entrepreneurship'. The guidelines and set up of an organisation are reflected in the behaviour of its leaders. According to Roxas and Coetzer (2012), in the context of small businesses, the stance is clear as the owners directly control the activities.

Many studies have provided evidence to show the beliefs, attitudes, intentions and prejudices of the owner of a small business largely determine the strategic position, direction and operations of the organisation, by allocating resources to specific projects and determining the activities to be carried out according to his/her vision (Sloan, Klingenberg \& Rider, 2013; Spence, 2007; Williams \& Schaefer, 2013). While these authors use different nomenclatures, they attribute the same meaning: the vision and personal values of the owner influence the organisation.

Roxas and Coetzer (2012) suggest that the tendency of small enterprises in a developing country, to know, to practice and to commit to a wide range of sustainability measures is largely driven by their owners, but also by their environment. Owners determine the strategic set up of their enterprises. However, the formation of sustainable attitudes is strongly influenced by the external environment, i.e. regulations, social norms and mental models that deeply affect the formation of positive and negative attitudes of the owners on issues related to the natural environmental. The 
importance of these factors is also emphasized in the work of Battisti and Perry (2011), Brammer, Hoejmose and Marchant (2012) and Studer, Welford and Hills (2006).

Similarly, Baden, Harwood and Woodward (2011) argue that legislation should be used to influence organisations to adopt social and environmental management systems. They suggest that in implementing changes required under government regulations, owners would come to adopt attitudes that will help them to better understand management. Nevertheless, Baden et al. (2011) also suggest that excessive legislation would not bring good results, as social and environmental management should be implemented on a more voluntarily basis.

Another major factor affecting the adoption of sustainability initiatives by SMEs relates to their reputation and stakeholder pressure (Borga, Citterio, Noci \& Pizzurno, 2009; Schaltegger, 2011; Williams \& Schaefer, 2013; Singh et al, 2014).

Regarding stakeholder pressure, the literature presents several points of view. In general, social attitudes and culture, in which environmental issues are only rarely considered, have produced little pressure on SMEs (Studer et al., 2006). Concerns and grievances are mainly directed at large organisations (Wilson, Williams \& Kemp, 2012) and this is probably due to low public visibility of SMEs (Bos-Brouwers, 2010). Johannsdottir (2015) and Lewis, Cassells and Roxas (2014) point out to a lack of pressure from stakeholders regarding sustainability issues in SMEs. In other words, stakeholder pressure does not seem to be a driver for the adoption of sustainability initiatives.

It can also be seen that the vast majority of small businesses adopt sustainability initiatives because they relate them to cost savings (Battisti \& Perry, 2011; Singh et al., 2014; Williams \& Schaefer, 2013). Laurinkevičiūtė and Stasiškienè (2011) believe the key driver for these businesses is profit. Singh et al. (2014) state that cost is the fundamental principle and driving force for any commercial activity. Thus, resource constraints in SMEs also require that the wastage level should be low and resource efficiency be high.

Whatever the nature of the business, the survival of the organisation depends on positive economic indicators. Moreover, in the context of SMEs, besides that enduring concern, the idea exists that incorporating sustainability initiatives involves expense (Baden et al., 2011; Revell \& Blackburn, 2007; Studer et al., 2006). For most SMEs, being sustainable requires investing resources that are unavailable to them (Bos-Brouwers, 2010; Nikolaou et al., 2015; Raufflet et al., 2014). In other words, the traditional lack of resources in SMEs hinders investment in sustainability.

However, considering SMEs typically lack resources, the most innovative organisations in terms of sustainability are those that have found ways to compensate for the shortage of resources (Bos-Brouwers, 2010). Choosing to integrate social and environmental issues can also produce business opportunities (Battisti \& Perry, 2011; Masurel, 2007), lead to differentiation through products and/or services (Schaltegger, 2011) and generate competitive advantage (Studer et al., 2006; Williams \& Schaefer, 2013).

For the managers of SMEs, one of the biggest problems hampering the adoption of sustainability initiatives may be their ignorance of the environmental damage their business produces (Nikolaou et al., 2015; Raufflet et al., 2014; Reverte, 2015). However, while SMEs may have less impact on the environment compared with large businesses, it does not mean they have no impact. On the contrary, waste generation and energy consumption levels in SMEs have a significant impact on the environment (Laurinkevičiūtė \& Stasiškienė, 2011).

Dalla, Gonçalves and Muniz (2009) point out that managers in SMEs often face a scarcity of resources, expertise and time when planning strategies, and consequently the decision-making process is simplified. Due to the complexity and frequent lack of clarity regarding the issues to be considered by managers, decisions are not based purely on rational operations. When attempting to choose a solution, managers may find uncertainty and/or a lack of information hamper decisionmaking. 
Borba et al. (2009) claim there is little sense of any potential benefit from implementing sustainability initiatives. That is, SMEs see no competitive advantage or benefits from adopting sustainability initiatives (Brammer et al., 2012), besides being unaware and ignorant of the pertinent legislation (Spence 2007; WilsoSIn et al., 2012), there is a lack of awareness regarding the advantages of forging and strengthening external partnerships (Lewis et al., 2014). Accordingly, Lourenço, Jones and Jayawarna (2012) defend the idea of promoting education in SMEs. Reiterating this point, Stewart and Gapp (2014) suggest the need for education programs for the implementation of sustainability initiatives.

For any real awareness to exist regarding the behaviour organisations should adopt in relation to the environment and society there must be an association between the organisational actors. The difficulty in implanting issues related to CSR may be partially explained by the lack of cross-company integration and the absence of effective networks (social or business), which together hamper cooperation between organisations (Bos-Brouwers, 2010; Lewis et al., 2014; Raufflet et al., 2014). According to Nikolaou et al. (2015), the shortage of financial resources and lack of knowledge about the impacts generated could be overcome through collaboration between organisations.

Santos and Silva (2010) report that in European countries, the rise of CSR among SMEs is mainly due to the opportunity to establish new partnerships, especially with large organisations. Greater cooperation has given rise to a significant increase in the impact of sustainable innovations (Bos-Brouwers, 2010). Moreover, incorporating sustainable and responsible initiatives into the management of SMEs may increase the possibility of their acting as suppliers to large organisations, thus improving their relationship with the whole supply chain (Lewis et al., 2014).

Government incentives are another factor that drive SMEs to adopt sustainability initiatives (Brammer et al, 2012; Williamson, Lynch-Wood \& Ramsay, 2006). The findings reported by Wilson et al. (2012) in their study among organisations in Hong Kong indicate lack of government support is one of the reasons for the poor adoption of environmental management principles. There are few public policies in this regard (Studer et al., 2006) and there are various political contradictions (Williams \& Schaefer, 2013). Corroborating these ideas, Nikolaou et al. (2015) state that many of the sustainability initiatives seen in SMEs serve only to meet the requirements of environmental legislation while providing no significant financial benefit. The limited resources of SMEs would suggest they are mare dependent on external support than large corporations (Studer et al., 2006). Finally, related to external support, there is a lack of specific guidelines for them regarding these issues (Borga et al., 2009; Bos-Brouwers, 2010). Based on the literature review, Table 1 presents our theoretical framework.

Table 1

Theoretical Framework

\begin{tabular}{|c|c|c|}
\hline $\begin{array}{l}\text { Analytical } \\
\text { Categories }\end{array}$ & Codes & Authors \\
\hline \multirow{4}{*}{$\begin{array}{l}\text { Internal } \\
\text { Factors }\end{array}$} & $\begin{array}{l}\text { Entrepreneur's } \\
\text { vision }\end{array}$ & $\begin{array}{l}\text { Baden et al. (2011); Battisti and Perry (2011); Bos-Brouwers (2010); Brammer } \\
\text { et al. (2012); Murillo and Lozano (2006); Roxas and Coetzer (2012); Santos } \\
\text { and Silva (2010); Schaper (2002); Sloan et al. (2013); Spence (2007); Williams } \\
\text { and Schaefer (2013) }\end{array}$ \\
\hline & $\begin{array}{c}\text { Lack of } \\
\text { knowledge }\end{array}$ & $\begin{array}{l}\text { Borga et al. (2009); Bos-Brouwers (2010); Brammer } \text { et al. (2012); Lewis } \text { et al. } \\
\text { (2014); Lourenço et al. (2012); Nikolaou et al. (2015); Raufflet et al. (2014); } \\
\text { Reverte (2015); Santos and Silva (2010); Spence (2007); Stewart and Gapp } \\
\text { (2014); Studer } \text { et al. (2006); Wilson } \text { et al. (2012) }\end{array}$ \\
\hline & $\begin{array}{l}\text { Lack of } \\
\text { resources }\end{array}$ & $\begin{array}{l}\text { Baden et al. (2011); Battisti and Perry (2011); Borga et al. (2009); Bos- } \\
\text { Brouwers (2010); Brammer et al. (2012); Nikolaou et al. (2015); Raufflet et } \\
\text { al. (2014); Revell and Blackburn (2007); Studer } \text { et al. (2006) }\end{array}$ \\
\hline & $\begin{array}{c}\text { Cost } \\
\text { reductions }\end{array}$ & $\begin{array}{l}\text { Battisti and Perry (2011); Masurel (2007); Schaltegger (2011); Singh et al. } \\
\text { (2014); Spence (2007); Studer et al. (2006); Williams and Schaefer (2013); } \\
\text { Wilson et al. (2012) }\end{array}$ \\
\hline
\end{tabular}

Revista de Gestão Social e Ambiental - RGSA, São Paulo, v. 11, n. 3, p. 21-36, set./dez. 2017. 


\begin{tabular}{|c|c|c|}
\hline \multirow{6}{*}{$\begin{array}{l}\text { External } \\
\text { Factors }\end{array}$} & $\begin{array}{c}\text { Business } \\
\text { opportunities }\end{array}$ & $\begin{array}{l}\text { Battisti and Perry (2011); Masurel (2007); Schaltegger (2011); Studer et al. } \\
\text { (2006); Williams and Schaefer (2013) }\end{array}$ \\
\hline & $\begin{array}{l}\text { Relationships } \\
\text { with other } \\
\text { organisations }\end{array}$ & $\begin{array}{l}\text { Bos-Brouwers (2010); Lewis et al. (2014); Raufflet et al. (2014); Nikolaou et } \\
\text { al. (2015); Santos and Silva (2010) }\end{array}$ \\
\hline & Reputation & $\begin{array}{l}\text { Borga et al. (2009); Laurinkevičiūtè and Stasiškienè (2011); Masurel (2007); } \\
\text { Schaltegger (2011); Studer et al. (2006); Williams and Schaefer (2013) }\end{array}$ \\
\hline & Legislation & $\begin{array}{l}\text { Baden et al. (2011); Battisti and Perry (2011); Brammer et al. (2012); Masurel } \\
\text { (2007); Roxas and Coetzer (2012); Studer et al. (2006) }\end{array}$ \\
\hline & $\begin{array}{l}\text { Stakeholder } \\
\text { pressure }\end{array}$ & $\begin{array}{l}\text { Borga et al. (2009); González-Benito and González-Benito (2006); } \\
\text { Johannsdottir (2015); Masurel (2007); Schaltegger (2011); Spence (2007); } \\
\text { Studer et al. (2006); Williams and Schaefer (2013) }\end{array}$ \\
\hline & $\begin{array}{l}\text { Government } \\
\text { incentives }\end{array}$ & $\begin{array}{l}\text { Brammer et al. (2012); Newell and Moore (2010); Revell and Blackburn } \\
\text { (2007); Studer et al. (2006); Williams and Schaefer (2013); Williamson et al. } \\
\text { (2006); Wilson et al. (2012) }\end{array}$ \\
\hline
\end{tabular}

The drivers for sustainability in SMEs identified in the 30 articles reviewed in the literature are the codes, which were grouped into two analytical categories: internal factors and external factors.

\section{METHODS}

This study adopted a qualitative approach with a multiple case study strategy. The sector chosen was the leather-footwear industry, because this sector is by far the largest generator of hazardous industrial solid waste in RS, with 62\% of the total (FEPAM, 2013). In addition, FEPAM (2013) points out that the municipalities of Estancia Velha (EV), Novo Hamburgo (NH) and Portão in RS, the southernmost state in Brazil, produce the highest levels of hazardous industrial solid waste, due to the large number of businesses in the leather and shoe industry in those municipalities.

To identify the cases for analysis, we contacted the Association of Leather and Skin Tanning Industries of EV (Sindicato das Indústrias de Curtimento de Couros e Peles de EV - SICCPEV), the Association of Tannery Industries of RS (Associação das Indústrias de Curtume do RS - AICSul), which provided information on the municipality $\mathrm{NH}$, and Association of Leather and Skin Tanning Industries of Portão (Sindicato das Indústrias de Curtimento de Couros e Peles de Portão SICCPP). The organisations selected must be SMEs and engaged in manufacturing, rather than just the marketing of leather products and footwear. Table 2 presents data on the number of organisations belonging to professional associations and the selected cases. Once the organisations eligible to participate in the research were identified, we contacted them by email and telephone. Eleven organisations agreed to take part in the survey, representing a multiple case study.

Table 2

Number of organisations selected for the survey

\begin{tabular}{cccc}
\hline Municipalities & $\begin{array}{c}\mathbf{N}^{\mathbf{0}} \text { Associated } \\
\text { Organisations }\end{array}$ & $\begin{array}{c}\mathbf{N}^{\mathbf{0}} \text { of Organisations Selected that } \\
\text { meet criteria }\end{array}$ & $\begin{array}{c}\mathbf{N}^{\mathbf{0}} \text { of organisations that agreed to } \\
\text { participate }\end{array}$ \\
\hline $\mathrm{EV}$ & 130 & $\mathbf{4 0}$ & $\mathbf{6}$ \\
$\mathrm{NH}$ & 100 & $\mathbf{4 4}$ & $\mathbf{4}$ \\
Portão & 20 & $\mathbf{1 9}$ & $\mathbf{1}$ \\
\hline
\end{tabular}

The data were collected using semi-structured interviews constructed with reference to the theoretical framework. The interview script was structured in three parts. The first (1) regarding the characteristics of the organisations, such as the motivations for starting the business and the owner's age, sex and level of education, size, localization, strategy, investment in R\&D, identified as relevant factors for sustainability initiatives in SMEs. The second (2), concerning sustainability initiatives, based on Global Reporting Initiative (GRI, 2014). Sustainability reports, traditionally 
seen as mechanisms of communication and transparency, are increasingly used as means of inserting CSR into the organisational management (Mio \& Venturelli, 2013; Zorio, García-Benau \& Sierra, 2013). GRI can be seen as a kind of guide for organisations to identify sustainability initiatives, therefore we used the initiatives presented by GRI to investigate the field. According GRI, we structured the instrument in four dimensions: social, environmental, vision and strategy; governance and management. In order to reduce the size of the instrument, we analysed each dimension and grouped the initiatives, resulting in 47 initiatives to be investigated. The third (3) examining factors for adoption, in which the questions sought to cause respondents to associate initiatives with adoption factors. We interviewed the business owners and their profiles are presented in Table 3. Throughout the text, in order to maintain confidentiality, the organisations are identified using acronyms: IND1-EV to IND6-EV, organisations from EV; IND1-NH to IND4-NH, organisations from NH and IND-POR, the organisation from Portão.

The documental research focused on collecting data from the organisations' websites and social networking sites as well as social reports when available. The objective was to identify the sustainability initiatives adopted and the intensity, or otherwise, of their reporting.

In addition, observations were made following the interviews, when the interviewees showed the researcher around their factories, including organisation facilities such as rooms where social project classes were held, residue treatment tanks and collection points for social campaigns.

Table 3

Respondent Profiles

\begin{tabular}{cccccc}
\hline Respondent & Organisation & Age & Sex & Education* & $\begin{array}{c}\text { Duration of the } \\
\text { interview }\end{array}$ \\
\hline R1 & IND1-EV & $45 \mathrm{yrs}$ & Male & UD & $40 \mathrm{~min}$ \\
R2 & IND2-EV & $55 \mathrm{yrs}$ & Male & UD & $48 \mathrm{~min}$ \\
R3 & IND3-EV & $51 \mathrm{yrs}$ & Male & HS & $1 \mathrm{~h} 10 \mathrm{~min}$ \\
R4 & IND4-EV & $38 \mathrm{yrs}$ & Male & UDI & $1 \mathrm{~h} 30 \mathrm{~min}$ \\
R5 & IND5-EV & $65 \mathrm{yrs}$ & Male & UDI & $43 \mathrm{~min}$ \\
R6 & IND6-EV & $41 \mathrm{yrs}$ & Male & HSI & $42 \mathrm{~min}$ \\
R7 & IND1-NH & $40 \mathrm{yrs}$ & Male & MBA & $52 \mathrm{~min}$ \\
R8 & IND2-NH & $49 \mathrm{yrs}$ & Fem & UD & $1 \mathrm{~h} 20 \mathrm{~min}$ \\
R9 & IND3-NH & 44 years & Male & Technical Training & $1 \mathrm{~h} 15 \mathrm{~min}$ \\
R10 & IND4-NH & 48 years & Fem & UD & $45 \mathrm{~min}$ \\
R11 & IND-POR & 35 years & Male & UD & $50 \mathrm{~min}$ \\
\hline
\end{tabular}

*UD-Undergraduate degree UDI-Undergraduate degree Incomplete

HS-High school HSI- High School Incomplete

Source: Research data (2015).

After the data collect, we separated the organisations according to the number of sustainability initiatives adopted. Thus, the following classification emerged: a) high presence, b) medium presence and c) low presence. The mean and standard deviation of the results found in the eleven analysed organisations were used to define the groups, the mean being 20 initiatives and the standard deviation 11. Hence, organisations with more than 31 initiatives were included in the 'high presence' group, organisations with 10-30 initiatives in the 'medium presence' group, and organisations with fewer than 9 initiatives in the 'low presence' group (Table 4). 


\section{Table 4}

Classification of the organisations according to number of sustainability initiatives (SIs).

\begin{tabular}{ccc}
\hline \multicolumn{3}{c}{ Classification of the organisations } \\
\hline High Presence & IND-POR & 40 SIs \\
(+31 SIs) & IND2-NH & 34 SIs \\
& IND3-NH & 33 SIs \\
\hline & IND4-EV & 25 SIs \\
Medium Presence & IND3-EV & 22 SIs \\
(10-30 SIs $)$ & IND5-EV & 18 SIs \\
& IND1-EV & 13 SIs \\
& IND4-NH & 10 SIs \\
\hline \multirow{2}{*}{ Low presence } & IND2-EV & 8 SIs \\
(-9 SIs) & IND6-EV & 8 SIs \\
& IND1-NH & 8 SIs \\
\hline
\end{tabular}

Once classified according to number of sustainability initiatives presented, the data were analysed using content analysis (Bardin, 2009). The categories used were internal factors and external factors. During the codification process, the codes were analysed using the frequency technique, which lists the number of times they are cited.

\section{RESULTS}

Organisational characteristics are fundamental for the incorporation of Sustainability initiatives (González-Benito \& González-Benito, 2006; Hansen \& Hamilton, 2011; Santos \& Silva, 2010). Hence, we start this section by presenting the characteristics of the organisations related to the presence level (high, medium and low) of sustainability initiatives. There seemed to no noticeable relationship between size and presence level, since there are small and medium-sized enterprises in the different classifications. The education level of the entrepreneurs does not seem to be a key feature in the group of studied organisations. It is interesting to note that the entrepreneur who had only high school is responsible for a company in the high presence group, while the company of the entrepreneur with a doctoral degree was in the low presence group. At the same way, there is no relations between gender the presence of sustainability initiatives. At all levels (high, medium and low), we found organisations with only men or men and women in managerial positions. IND-POR (high presence) and IND6-EV (low presence) have only men running the business, while IND1-NH (low presence) and IND2-NH (high presence) have women in the management. Similarly, maturity (organisation age) appeared not to affect the level of presence. IND-POR has been in operation for 103 years and has a high presence, while IND2-EV is 90 years old and has a low presence. Additionally, we found no relationship between the different types of customers and suppliers and level of presence, since there are different scopes in the three classifications.

Contrary to some findings reported in the literature, the analysis of the organisational characteristics alone showed no relationship with the presence of sustainability initiatives. However, interesting findings were identified when these characteristics were combined with the adoption factors, described below.

\subsection{Internal and External Factors}

For CSR to be meaningful, it must be related to two sources: a) internal corporate attitudes, which refer to how the organisation carries out the daily operations of its main functions; and b) external corporate attitudes, related to the organisation's participation beyond its direct business interests (Aguinis \& Glavas, 2012; Johannsdottir, 2015). These corporate attitudes, whether internal or external, require the adoption of initiatives that reflect a concern for SD. Analysis of the evidence cited by the interviewees led to the development of Figure 1, establishing the cross-referencing of 
internal and external factors that influence the adoption and level of presence of Sustainability initiatives among the studied organisations.

The most outstanding internal factor is the 'Entrepreneur's vision', demonstrating the importance of the owner's role in the adoption of sustainability initiatives. When the owner supports and encourages the adoption of sustainability initiatives, the employees are engaged. This result reinforces the literature where many studies show that the owners of a small businesses largely determine strategy (Roxas \& Coetzer, 2012, Sloan et al., 2013; Spence, 2007; Williams \& Schaefer, 2013). Subsequently, 'Cost reductions' and 'Lack of resources' are the next most cited internal factors, each one with the same frequency. Only cited by high and medium level. 'Lack of knowledge' was not mentioned. Therefore, only three internal factors were identified in this research.

The external factor 'Legislation' was identified in all the organisations, regardless of level of presence of sustainability initiatives. 'Legislation' was identified as being a determining factor since none of the organisations in the sample was found to have no sustainability initiatives. This result contrasts with that of Laurinkevičiūte and Stasiškienè (2011), who suggest that SMEs are unfamiliar with the legislation and the environmental obligations, resulting, in most cases, in the absence of sustainability initiatives.

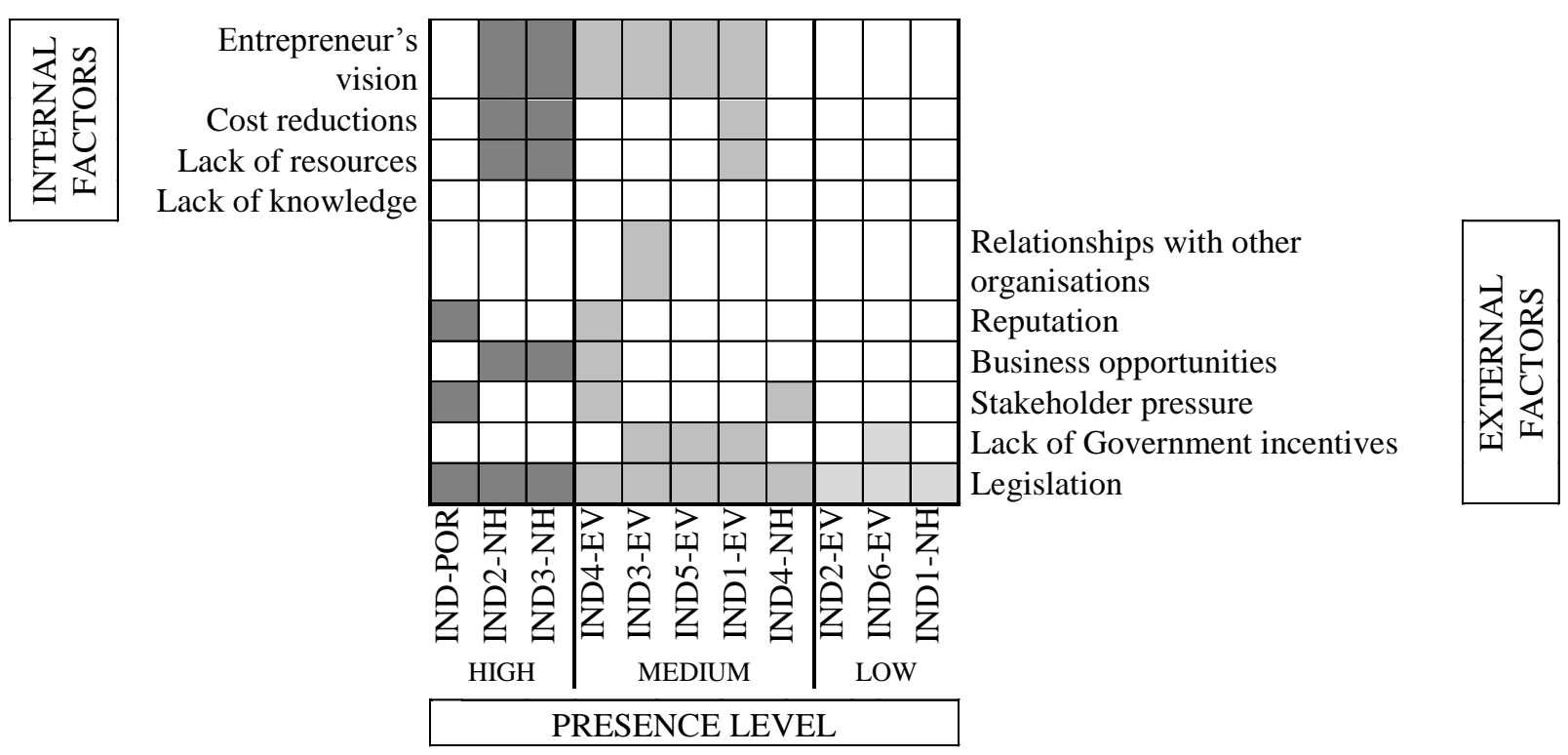

Figure 1. Cross-referencing the Internal and External Factors.

'Government incentives' were the second most cited external factor. The striking feature regarding this factor was that the interviewees' referred only to the absence of any such incentives. In this way, more than a facilitator factor, the lack of government incentives represents an inhibitory factor to the adoption by organisations of a greater number of sustainability initiatives. Accordingly, we changed the name of the factor to 'Lack of government incentives'. Our results reinforce the findings reported in the literature, by not only highlighting that 'Government incentives' is a factor that drives the involvement of SMEs in relation to the adoption of sustainability initiatives (Strand, Freeman \& Hockerts, 2015; Brammer et al., 2012; Williamson et al., 2006), but also that there are still few such public policies (Studer et al., 2006).

'Stakeholder pressure' and 'Business opportunities' were cited by three organisations and 'Reputation' by two. These factors were observed in organisations with high and medium presence of sustainability initiatives. The same organisations that cited 'Reputation' also cited 'Stakeholder pressure'. For them, these factors are directly related to corporate image. 
It is interesting to see how the associate three factors: 'Cost reductions' and 'Lack of resources' (Internal factors) and 'Business opportunities' (External factor). In several organisations, the interviewees referred to possible initiatives involving the reuse of waste and raw materials that would represent opportunities to produce alternative products, thus generating income and/or reducing costs, which due to the lack of resources were not introduced.

The analysis of the initiatives considering each dimension of the GRI separately did not indicate any relation with the adoption factors. The only result that deserves to be highlighted is that no organizations with a low presence showed any initiatives focused on vision and strategy (management dimension).

\section{DISCUSSION}

We have four aspects to discuss. First, we proposed a single framework to sustainability drivers in SMEs. Second, we discuss the internal and external factors as two sides of the same coin. In the third aspect, we highlight a gender issue involving the woman's consciousness. Finally, we discuss the role of government and legislation in SME`s, raising two propositions.

\section{Sustainability drivers in SMEs: A single framework}

A comparison of the responses from the studied organisations enabled us to understand the factors that facilitate and hinder the adoption of sustainability initiatives. Thus, we were able to build a matrix, cross-referencing the internal and external factors in relation to the inhibiting and facilitating factors the organisations identified regarding the intensity of their engagement with the sustainability initiatives (Figure 2). We highlight the most significant factors in each of the quadrants according to the evidence presented by the interviewees (Figure 2). The factor 'Legislation' is highlighted in grey because it was the only factor found to influence all the organisations and seems to be fundamental for the adoption of sustainability initiatives.

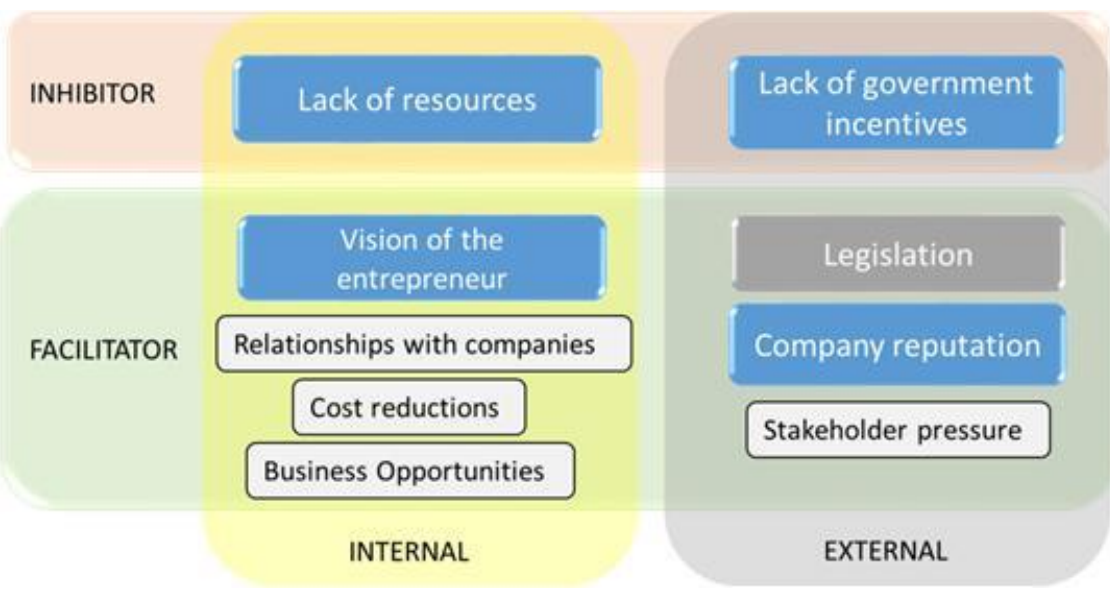

Figure 2. A framework to sustainability factors in SMEs.

The inhibitory factors can be considered potential facilitators, since in all cases they were cited due to their absence. That is, if we analyse the internal inhibitory factors 'lack of resources' and 'lack of knowledge', we can assume that the availability of resources and knowledge might facilitate the adoption of sustainability initiatives.

One factor identified in the literature, 'Lack of knowledge', was not cited by the respondents, which leads us to ask the question - Could there be a lack of awareness among the respondents regarding their own lack of knowledge in relation to sustainability initiatives? Furthermore, the factor 'Relationships with other organisations' was only cited by one organisation. According to Nikolaou et al., (2015), limited financial resources and lack of knowledge regarding the impacts generated could be overcome through collaboration between such organisations. In 
other words, this relationship could stimulate resource sharing, by minimizing the effects of the internal inhibitory factor 'lack of resources', and leveraging knowledge. Santos and Silva (2010) reported that in European countries, the increase in CSR among SMEs is due to the opportunity of establishing new partnerships, especially with large organisations. Finally, according to BosBrouwers (2010) more alliances and cooperation would bring about a significant increase in the impact of sustainable innovation. In other words, building relationships with other organisations may be one way for SMEs to make progress in the adoption of sustainability initiatives, not only as a factor in itself, but as a means of overcoming other barriers such as lack of resources.

\section{Internal and external factors: two sides of the same coin}

Internal factors are only mentioned by organisations with high and medium levels of presence, indicating the organisations with a low presence are responding to the external environment rather than presenting a proactive behaviour. The "entrepreneur's vision" is clearly the most influential internal factor. As stated by Baumgartner (2009), if sustainability is not part of the values held by the organisation's leaders and members, any such initiatives are likely to fail. However, two organisations did not mention any internal factor, namely IND-POR (high presence) and IND4-NH (medium presence). So what explains their high and medium levels of presence? These same organisations cite the influence of external factors related to image - 'Stakeholder pressure' and 'Reputation'. Hence, this may indicate that in the absence of perceived relevant internal factors, the organisation may adopt sustainability initiatives to some degree because of external factors related to corporate image. According to Testa, Gusmerottia, Corsini, Passetti and Iraldo (2015), external pressures and the entrepreneurs' attitudes are the most important predictors of environmental proactivity for small and micro firms.

Our findings indicate there are two possible paths lead to the adoption of sustainability initiatives by SMEs: one based on the values held by the leaders and members of the organisation and the other guided by concern for the organisation's reputation.

All the organisations that mentioned 'stakeholder pressure' and 'reputation' are over 5 years old and two of the three are medium-sized. These characteristics (age and size) are the two antecedents with the greatest effect on corporate reputation (Raza et al., 2015), which explains the importance of 'Stakeholder pressure' and 'Reputation'. Some results found in the literature point out that, in general, the prevailing social attitude, produces little pressure on SMEs (Studer et al., 2006). Such concerns and grievances are more frequently focused on large organisations (Wilson et al., 2012), in part due to the low visibility of SMEs among the public (Bos-Brouwers, 2010). Regarding the implications of these findings, society could play a more effective role in achieving SD by paying greater attention to older and larger SMEs rather than just focusing on large organisations.

\section{Women's consciousness}

As to gender, we highlight that those organisations in which women held managerial positions there was a strong relationship with the internal factor 'Entrepreneur's vision'. This corroborates the findings of Alonso-Almeida et al. (2015) who found female students are more concerned about social and environmental issues. Moreover, they noted that the higher the positions held by women in organisations, the more socially responsible those organisations were. Landry, Bernardi and Bosco (2016) indicate that the higher the percentage of women on a organisation's board of directors, the more sustained Corporate Social Responsibility is in the organisation. On the one hand, strengthening this link between the factors 'Entrepreneur's vision' and the 'Participation of women in management', IND-POR has no women in management positions and did not present the factor 'Entrepreneur's vision'. On the other hand, the same organisation, IND-POR presented a high presence, even without the factor 'Entrepreneur's vision', reinforcing the relevance of the two possible paths to the adoption of sustainable initiatives highlighted above. 


\section{The role of government and legislation in small and medium-sized enterprises}

'Legislation' is the only factor found to influence all the organisations and appears to be at the root of the adoption of sustainability initiatives. However, although it seems to be a determining factor, when legislation was the only factor, it is related to organisations with a low presence of sustainability initiatives.

In addition, we found that while those organisations with a high and medium presence of sustainability initiatives do not report the absence of government incentives - in contrast to almost all the organisations with a medium presence. What might these results mean? It may be the case that the lack of government incentives represents an important factor to hindering organisations from adopting a greater number of sustainability initiatives.

Two propositions emerge from these discussions: (1) the exclusive presence the factor legislation is associated a low levels of presence of sustainability initiatives and (2) the 'lack of government incentives' hinders organisations from adopting a greater number of sustainability initiatives.

\section{CONCLUSIONS}

The fact that legislation has a fundamental role in the adoption or otherwise of sustainability initiatives by small and medium-size enterprises would seem to suggest they assume a reactive posture. Those that proactively progress along the path towards sustainability do so in one of two ways. One is based upon the entrepreneur's vision, and the other guided by concern regarding the organisation's reputation. That is, internal and external factors appear to have the same force, depending on the organisation's characteristics.

The biggest obstacle to small and medium-sized enterprises improving their performance in adopting a larger number of sustainability initiatives seems to be a lack of government incentives. This constitutes an important inhibitory factor and can be considered one of the reasons for the low adherence to the principles of socio-environmental management. In our research, the drivers we found that lead SMEs to adopt sustainability initiatives have been organized into a framework.

As a theoretical contribution, we identified two propositions to be tested: (1) the exclusive presence the factor legislation is associated to low levels of presence of sustainability initiatives and (2) the lack of government incentives hinders organisations in low and medium levels from adopting a greater number of sustainability initiatives. Going beyond, if the second one is true, what other factors can overcome it? Because in our results, organisations with high level do not mention lack of government incentives. Then, either there are other factors to adopt more initiatives or speech about lack of government incentives is an excuse for not doing more. Furthermore, our framework can be used in quantitative studies to establish which factors are dependent and/or independent variables in order to identify the degree of correlation between them. For example, since legislation factor appears to be fundamental for the adoption of sustainability initiatives, which factors are dependent variables? Considering the perspectives: (1) internal and external, and (2) facilitators and inhibitors, the antecedents and consequences could be tested considering different moderating variables such as business sector or country.

In terms of its contribution to practice, we believe that this framework can be of use to SMEs that are interested in conducting an organisational diagnosis and planning sustainability initiatives. Often organisations focus on facilitating factors rather than examining inhibitors. While the existence of facilitating factors is a necessary condition, perhaps it is not sufficient in itself.

\section{REFERENCES}

Aguinis, H., \& Glavas, A. (2012). What we know and don't know about corporate social responsibility a review and research agenda. Journal of management, 38(4), 932-968. 
Ali, R., Lynch, R., Melewar, T. C., \& Jin, Z. (2015). The moderating influences on the relationship of corporate reputation with its antecedents and consequences: A meta-analytic review. Journal of Business Research, 68(5), 1105-1117.

Alonso-Almeida, M. D. M., Fernández de Navarrete, F. C., \& Rodriguez-Pomeda, J. (2015). Corporate social responsibility perception in business students as future managers: a multifactorial analysis. Business Ethics: A European Review, 24(1), 1-17.

Amran, A., Lee, S. P., \& Devi, S. S. (2014). The influence of governance structure and strategic corporate social responsibility toward sustainability reporting quality. Business Strategy and the Environment, 23(4), 217-235.

Baden, D., Harwood, I. A., \& Woodward, D. G. (2011). The effects of procurement policies on 'downstream'corporate social responsibility activity Content-analytic insights into the views and actions of SME owner-managers. International Small Business Journal, 29(3), 259-277.

Bardin, L. (2009). Análise de Conteúdo. Lisboa: Edições, 70.

Battisti, M., \& Perry, M. (2011). Walking the talk? Environmental responsibility from the perspective of small-business owners. Corporate Social Responsibility and Environmental Management, 18(3), 172-185.

Baumgartner, R. J. (2009). Organizational culture and leadership: Preconditions for the development of a sustainable corporation. Sustainable Development, 17(2), 102-113.

Borga, F., Citterio, A., Noci, G., \& Pizzurno, E. (2009). Sustainability report in small enterprises: case studies in Italian furniture companies. Business Strategy and the Environment, 18(3), 162-176.

Bos-Brouwers, H. E. J. (2010). Corporate sustainability and innovation in SMEs: evidence of themes and activities in practice. Business Strategy and the Environment, 19(7), 417-435.

Brammer, S., Hoejmose, S., \& Marchant, K. (2012). Environmental management in SMEs in the UK: practices, pressures and perceived benefits. Business Strategy and the Environment, 21(7), 423-434.

Carroll, A. B. (1999). Corporate social responsibility evolution of a definitional construct. Business \& society, 38(3), 268-295.

Dalla, W. D., Gonçalves, C. A., \& Muniz, R. M. (2009). O pensamento do estrategista: fatores que asseguram a tomada de decisões estratégicas nas pequenas e médias empresas. Revista Ibero Americana de Estratégia, 8(2), 80-106.

Elkington, J. (1998). Partnerships from cannibals with forks: The triple bottom line of 21st-century business. Environmental Quality Management, 8(1), 37-51.

FEPAM, 2013. Relatório sobre a geração de resíduos sólidos industriais no estado do Rio Grande do Sul (accessed 12.04.14.). http://www.fepam.rs.gov.br/biblioteca/rsi.asp.

Fifka, M. S., \& Drabble, M. (2012). Focus and standardization of sustainability reporting-a comparative study of the United Kingdom and Finland. Business Strategy and the Environment, 21(7), 455-474. 
Gallardo-Vázquez, D., \& Sanchez-Hernandez, M. I. (2014). Measuring corporate social responsibility for competitive success at a regional level. Journal of Cleaner Production, 72, 14-22.

Garriga, E., \& Melé, D. (2004). Corporate social responsibility theories: Mapping the territory. Journal of business ethics, 53(1-2), 51-71.

González-Benito, J., \& González-Benito, Ó. (2006). A review of determinant factors of environmental proactivity. Business Strategy and the environment, 15(2), 87-102.

GRI. (2014). G4 Sustainability Reporting Guidelines (accessed 08.10.14). http://www.globalreporting.org/reporting/g4.

Halme, M., \& Korpela, M. (2014). Responsible Innovation toward sustainable development in small and medium-sized enterprises: a resource perspective. Business Strategy and the Environment, 23(8), 547-566.

Hansen, B., \& Hamilton, R. T. (2011). Factors distinguishing small firm growers and nongrowers. International small business journal, 29(3), 278-294.

Institute Ethos. (2013). Indicadores Ethos para negócios sustentáveis e responsáveis (accessed 07.10.13.). http://www3.ethos.org.br/conteudo/iniciativas/indicadores.

Johannsdottir, L. (2015). Drives of proactive environmental actions of small, medium and large Nordic non-life insurance companies-and insurers as a driving force of actions. Journal of Cleaner Production, 108, 685-698.

Landry, E. E., Bernardi, R. A., \& Bosco, S. M. (2014). Recognition for sustained corporate social responsibility: female directors make a difference. Corporate Social Responsibility and Environmental Management. 23, 27-36.

Laurinkevičiūtè, A., \& Stasiškienè, Ž. (2011). SMS for decision making of SMEs. Clean Technologies and Environmental Policy, 13(6), 797-807.

Lewis, K. V., Cassells, S., \& Roxas, H. (2015). SMEs and the potential for a collaborative path to environmental responsibility. Business Strategy and the Environment, 24(8), 750-764.

Lourenço, F., Jones, O., Jayawarna, D. (2012). Promoting sustainable development: The role of entrepreneurship education. International Small Business Journal.

Lozano, R. (2015). A holistic perspective on corporate sustainability drivers. Corporate Social Responsibility and Environmental Management, 22(1), 32-44.

Masurel, E. (2007). Why SMEs invest in environmental measures: sustainability evidence from small and medium-sized printing firms. Business Strategy and the Environment, 16(3), 190-201.

Mio, C., \& Venturelli, A. (2013). Non-financial Information About Sustainable Development and Environmental Policy in the Annual Reports of Listed Companies: Evidence from Italy and the UK. Corporate Social Responsibility and Environmental Management, 20(6), 340-358. 
Moyeen, A., \& Courvisanos, J. (2012). Corporate Social Responsibility in Regional Small and Medium-Sized Enterprises in Australia. Australasian Journal of Regional Studies, 18(3), 364.

Murillo, D., \& Lozano, J. M. (2006). SMEs and CSR: An approach to CSR in their own words. Journal of Business Ethics, 67(3), 227-240.

Newell, C. J., \& Moore, W. B. (2010). Creating small business sustainability awareness. International Journal of Business and Management, 5(9), 19-25.

Nikolaou, I. E., Nikolaidou, M. K., \& Tsagarakis, K. P. (2016). The response of small and mediumsized enterprises to potential water risks: an eco-cluster approach. Journal of Cleaner Production, 112, 4550-4557.

Raufflet, E., Cruz, L. B., \& Bres, L. (2014). An assessment of corporate social responsibility practices in the mining and oil and gas industries. Journal of Cleaner production, 84, 256-270.

Revell, A., \& Blackburn, R. (2007). The business case for sustainability? An examination of small firms in the UK's construction and restaurant sectors. Business Strategy and the Environment, 16(6), 404-420.

Reverte, C. (2015). The new Spanish corporate social responsibility strategy 2014-2020: A crucial step forward with new challenges ahead. Journal of Cleaner Production, 91, 327-336.

Roxas, B., \& Coetzer, A. (2012). Institutional environment, managerial attitudes and environmental sustainability orientation of small firms. Journal of Business Ethics, 111(4), 461-476.

Schaltegger, S. (2011). Sustainability as a driver for corporate economic success: Consequences for the development of sustainability management control. Society and Economy, 33(1), 15-28.

Schaper, M. (2002). Small firms and environmental management predictors of green purchasing in western Australian pharmacies. International Small Business Journal, 20(3), 235-251.

Santos, M. J. N., \& da Silva, R. R. (2010). A importância da responsabilidade social corporativa para a potenciação do capital social em pequenas e médias empresas. Ciencias $d a$ Administração, 12(27), 190-207.

Singh, S., Olugu, E. U., \& Fallahpour, A. (2014). Fuzzy-based sustainable manufacturing assessment model for SMEs. Clean Technologies and Environmental Policy, 16(5), 847-860.

Sloan, K., Klingenberg, B., \& Rider, C. (2013). Towards sustainability: Examining the drivers and change process within SMEs. Journal of Management and Sustainability, 3(2), 19.

Spence, L. J. (2007). CSR and small business in a European policy context: the five "C" s of CSR and small business research agenda 2007. Business and society review, 112(4), 533-552.

Stewart, H., \& Gapp, R. (2014). Achieving Effective Sustainable Management: A Small-Medium Enterprise Case Study. Corporate Social Responsibility and Environmental Management, 21(1), 5264.

Strand, R., Freeman, R. E., \& Hockerts, K. (2015). Corporate social responsibility and sustainability in Scandinavia: An overview. Journal of Business Ethics, 127(1), 1-15. 
Studer, S., Welford, R., \& Hills, P. (2006). Engaging Hong Kong businesses in environmental change: drivers and barriers. Business Strategy and the Environment, 15(6), 416-431.

Testa, F., Gusmerottia, N. M., Corsini, F., Passetti, E., \& Iraldo, F. (2015). Factors affecting environmental management by small and micro firms: The importance of entrepreneurs' attitudes and environmental investment. Corporate Social Responsibility and Environmental Management.

Williams, S., \& Schaefer, A. (2013). Small and medium-sized enterprises and sustainability: Managers' values and engagement with environmental and climate change issues. Business Strategy and the Environment, 22(3), 173-186.

Williamson, D., Lynch-Wood, G., \& Ramsay, J. (2006). Drivers of environmental behaviour in manufacturing SMEs and the implications for CSR. Journal of Business Ethics, 67(3), 317-330.

Wilson, C. D., Williams, I. D., \& Kemp, S. (2012). An evaluation of the impact and effectiveness of environmental legislation in small and medium-sized enterprises: Experiences from the UK. Business Strategy and the Environment, 21(3), 141-156.

Zorio, A., García-Benau, M. A., \& Sierra, L. (2013). Sustainability development and the quality of assurance reports: Empirical evidence. Business strategy and the environment, 22(7), 484-500.

Data da submissão: 13/05/2017

Data de aceite: $22 / 11 / 2017$ 